\section{(1) \\ CrossMark}

\title{
The frequent and underrecognised co-occurrence of acute exacerbated COPD and depression warrants screening: a systematic review
}

\author{
Leopold Lecheler ${ }^{1}$, Maximilian Richter ${ }^{2}$, Daniel P. Franzen ${ }^{3}$, \\ Silvana K. Rampini $i^{1,4}$, Marcus Cheetham ${ }^{1,4,5}$, Josef Jenewein ${ }^{6}$, \\ Edouard Battegay ${ }^{1,4,5}$ and Albina Nowak ${ }^{1,4}$
}

Affiliations: ${ }^{1}$ Center of Competence Multimorbidity, University Hospital Zurich, University of Zurich, Zurich, Switzerland. ${ }^{2}$ Dept of Urology, Technische Universität Dresden, Dresden, Germany. ${ }^{3}$ Dept of Respiratory Medicine, University Hospital Zurich, University of Zurich, Zurich, Switzerland. ${ }^{4}$ Dept of Internal Medicine, University Hospital Zurich, Zurich, Switzerland. ${ }^{5}$ University Research Priority Program “Dynamics of Healthy Aging", University of Zurich, Zurich, Switzerland. 'Dept of Psychiatry and Psychotherapy, University Hospital Zurich, University of Zurich, Zurich, Switzerland.

Correspondence: Leopold Lecheler, Center of Competence Multimorbidity, University Hospital Zurich, University of Zurich, 8132 Egg bei Zurich, Switzerland. E-mail: leopold.lechelerlagmail.com

@ERSpublications

Patients hospitalised for AECOPD should be screened for depression and treatment recommendations should be developed http://ow.ly/plg430bspOA

Cite this article as: Lecheler L, Richter M, Franzen DP, et al. The frequent and underrecognised co-occurrence of acute exacerbated COPD and depression warrants screening: a systematic review. Eur Respir Rev 2017; 26: 170026 [https://doi.org/10.1183/16000617.0026-2017].

ABSTRACT Patients with acute exacerbated chronic obstructive pulmonary disease (AECOPD) and concurrent depression suffer significant psychological stress and decreased quality of life. The aim of this study was to collate data, guidelines and recommendations from publications on the screening and management of depressive mood disorders in patients hospitalised with AECOPD.

We systematically searched four databases for publications reporting screening or management of depression in patients hospitalised for AECOPD. The identification of articles was based on the Preferred Reporting Items for Systematic Reviews and Meta-Analyses (PRISMA) statement.

Out of 1494 original articles screened, 35 met all inclusion criteria. These report a prevalence of depression in AECOPD ranging between 9.5\% and 85.6\%. Some studies report high postadmission mortality rates for depressive AECOPD patients, and higher readmission rates in depressive versus nondepressive AECOPD patients. Importantly, none of the 35 publications included suggestions on the screening and management of depression in AECOPD.

Depression and AECOPD frequently co-occur, and this worsens outcomes. Yet we did not find recommendations on management, and few interventional studies. Patients hospitalised with AECOPD should be systematically screened for depression and treatment recommendations should be developed for these patients. Randomised studies on how to screen and treat depression in hospitalised AECOPD are necessary.

Received: March 192016 | Accepted after revision: April 262017

Conflict of interest: None declared.

Provenance: Submitted article, peer reviewed.

Copyright OERS 2017. ERR articles are open access and distributed under the terms of the Creative Commons Attribution Non-Commercial Licence 4.0. 


\section{Introduction}

Chronic obstructive pulmonary disease (COPD) is a progressively incapacitating multisystem disease that worsens the patient's physical and psychosocial functioning $[1,2]$. Thus, functional impairment in COPD is known to lead to psychiatric comorbidity [3-5], e.g. elevated incidence of depression [5]. Contrariwise, depression adversely affects functional ability and quality of life in COPD. Furthermore, depression is a risk factor for readmission to hospital for acute exacerbation of COPD (AECOPD) [6-8].

The pathophysiological mechanisms underpinning the relationship between AECOPD and depression are not well understood (for a detailed review, see [9]). For example, physical limitations, hypoxia, smoking and "overspilling" lung inflammation appear to elevate levels of personal distress and depressive mood [8], but the degree of personal distress does not depend on the severity of lung disease [10]. Systemic short-term glucocorticoid therapy for AECOPD does not trigger depressive mood symptoms [11], but inflammation and long-term administration of glucocorticoids contribute to depressive mood disorders [12-14].

Given the harmful interactions between COPD and depression, it is noteworthy that depression is widely underdiagnosed and undertreated in patients with COPD [8], even if these harmful interactions are not well understood. Nevertheless, the Swiss guideline on management of COPD lacks attention to the patient's state of mind and depressed mood [15]. It focuses solely on the treatment of the underlying respiratory disease and symptoms, even though depression is a common comorbidity. Other important guidelines provided by the Global Initiative for Chronic Obstructive Lung Disease (GOLD) and the National Institute for Health and Care Excellence acknowledge the high prevalence of depression in COPD patients, but they lack advice on screening or intervention for depression [16, 17].

This is the first systematic review assessing the prevalence of depressive mood disorders in patients primarily hospitalised due to AECOPD and collating recommendations for the screening and management of this comorbidity.

\section{Methods}

\section{Search strategy}

We conducted a comprehensive search of all publications until October 6, 2015, using the databases MEDLINE, Embase and the Cochrane Library. Previous research in other fields of medicine has shown that combining the databases of MEDLINE, Embase and Cochrane can yield a recall rate as high as $97 \%$ [18]. Hence, missing relevant publications is very unlikely. Nevertheless, we included PsycINFO to identify publications with a more psychotherapeutic focus. The database searches focused on English language publications, irrespective of country of origin, relating to patients hospitalised for AECOPD, depression in AECOPD and interventions for management of depression in AECOPD.

The search terms are summarised in table 1. These terms were combined using the Boolean operator "and" to search through titles, abstracts and key words. After selecting articles, we merged the results from the four databases and eliminated any duplicates, using EndNote X7 (Thomson Reuters, Zug, Switzerland).

\section{Selection criteria}

The review included all articles fulfilling the inclusion criteria, i.e. study related to a hospitalised population of AECOPD, screening and/or management for depression and availability as a full-text article. Articles not written in English and articles without abstracts were excluded. The selection criteria were developed according to the Preferred Reporting Items for Systematic Reviews and Meta-Analyses (PRISMA) statement [19].

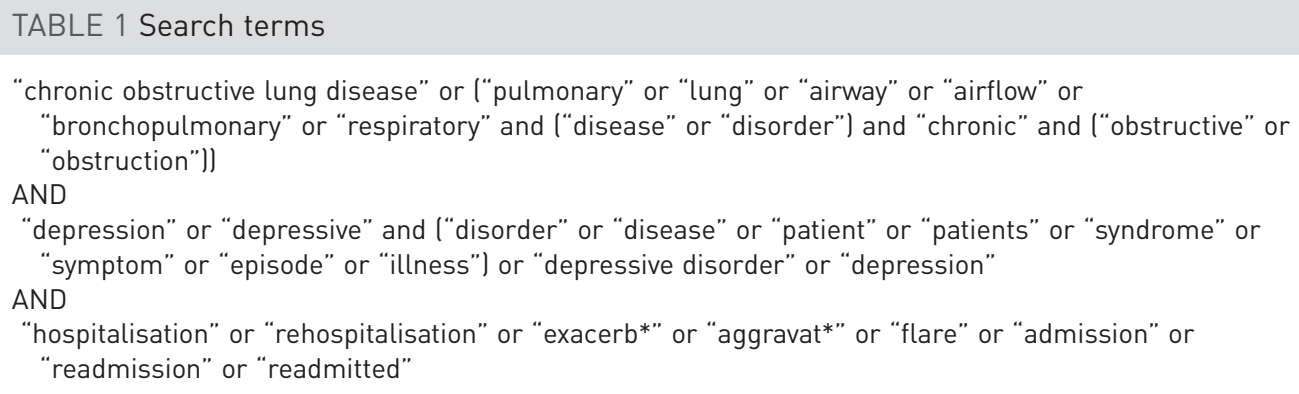




\section{Study selection}

LL initially searched the electronic databases. Subsequently, a screening of the abstracts based on the inclusion criteria was conducted. The inclusion criteria are summarised in table 2 . If screening of abstracts was inconclusive, the full-text article was screened for the criteria. Disagreements were resolved by consensus between the authors LL, MR, DF and AN.

\section{Data extraction}

The data were extracted by one author (LL) from each publication according to the following categories: study type, characteristics of population, number of patients, evaluation of depression, outcome of readmission rate, outcome of mortality, follow-up, intervention and results. Another author (AN) checked the extracted data. Figure 1 shows a flow chart of the process of study selection.

\section{Quality assessment}

For quality assessment, a randomly selected $10 \%$ of the initial publication sample was reviewed by the coauthors AN, MR and DF. The results were compared and discrepancies discussed. Disagreements were resolved by consensus between the authors LL, MR and DF.

\section{Results}

Identification of publications

The initial search generated a total of 1793 publications from the four databases. There were 1494 publications after removal of all duplicates. 80 of these publications were referred to full text review because screening of the abstracts indicated eligibility for our study. After reviewing the full texts, 35 publications met all inclusion criteria [8,20-53]. Seven of these were reviews, 11 conference abstracts and 17 were full-text studies. No further publications were found by checking the reference lists of these articles.

The 35 publications provide data about depression within a population of hospitalised patients due to AECOPD. In nine of them, readmissions between 1 month and 1 year were reported. Mortality was assessed in six studies covering a range of $\leqslant 2$ years. Table 3 shows a summary of all 35 studies that met the inclusion criteria.

\section{Prevalence of concurrent depression in hospitalised AECOPD patients}

The 35 final publications described depression and AECOPD as a frequent comorbidity in hospitalised patients. The prevalence of depression was high or very high according to all publications, ranging from 9.5\% to $85.6 \%$. However, the methods used for the assessment of depression were different, since the tools to screen for depression, severity criteria and timeframe in which depression was evaluated during exacerbation phase varied among the publications included.

\section{Therapeutic guidelines for concurrent depression and AECOPD}

None of the 35 publications included suggestions, guidance or guidelines for treatment of depression in patients with AECOPD. However, three studies investigated interventions applied in those patients (see later). Of the seven reviews, none gave advice regarding therapy adjustments in depressive AECOPD patients. All seven reviews focused on the impact and relationship of depression on COPD, with three targeting the effect on exacerbation rates from depression in COPD patients. Depression is found to be uniformly high in COPD patients, correlating with a worse outcome regarding survival, hospitalisation rates and symptoms. However, none gave specific recommendations regarding operationally usable potential methods of screening or treatment for patients hospitalised for a primary diagnosis of AECOPD $[8,29,38,39,42,44,46]$.

Table 3 provides a summary of the depression and assessment methods used in the articles reviewed.

\section{TABLE 2 Inclusion criteria}

Studies including participants primarily hospitalised due to an acute exacerbation of chronic obstructive pulmonary disease
AND a screening for depressive mood disorders in those patients AND/OR a guided management of depressions in those patients 
FIGURE 1 Identification of eligible studies.

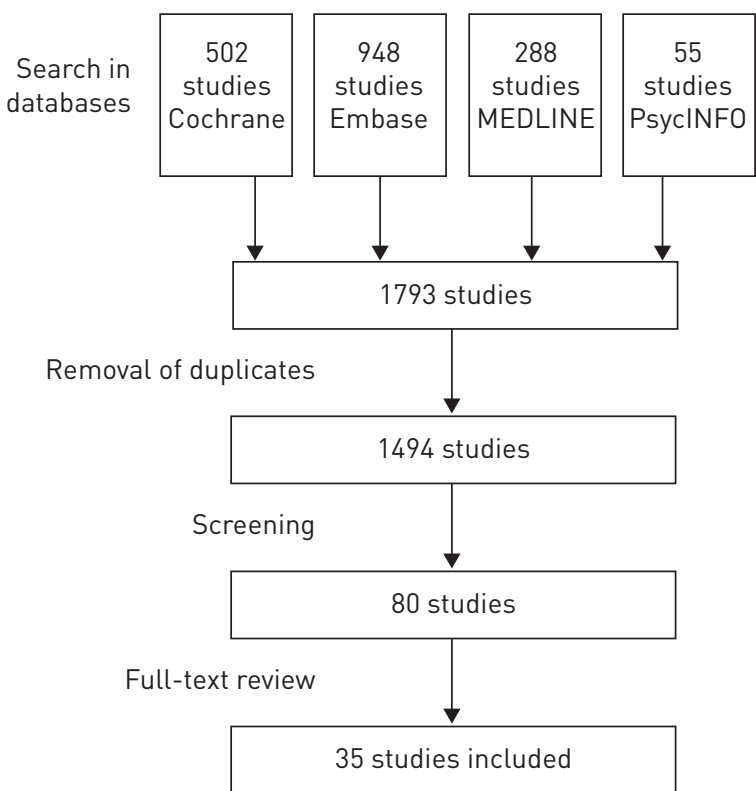

Readmission rate and mortality

Readmission after hospitalisation due to AECOPD was investigated in seven of the publications included $[20,22,26,31,34,35,43,48]$. 30-day and 1-year readmission rates were $10.4-24.1 \%$ and $29.0-84.6 \%$, respectively. Four out of these seven studies reported a significantly higher readmission rate in depressive compared with nondepressive AECOPD patients (20-84.6\% versus 16-28.1\%) [26, 31, 43, 48].

Mortality in depressive patients hospitalised for AECOPD was investigated in six publications [21, 22, 27, $40,43,47$. 30-day and 1-year mortality rates were $5.3-7.2 \%$ and $9.8-25.3 \%$, respectively. Five of these studies stated a significantly higher mortality in depressive patients during the follow-up period between 30 days and 2 years compared to nondepressive patients [21, 22, 26, 40, 43]. One study failed to find a higher mortality in depressive AECOPD patients. However, while other studies focused on post-discharge mortality, this study investigated in-hospital mortality [47].

\section{Treatment interventions}

Three publications considered therapeutic interventions. An adjusted regime of physical therapy [51, 52] and a programme of counselling and education of the inpatient and primary health care team were investigated [34].

The physical therapeutic interventions were based on a combination of deep breathing and limb exercises daily for 30-45 min in one study and a controlled breathing programme twice daily for $30 \mathrm{~min}$ in the second study. Both showed a significant effect on the outcome of depression. Patients showed improvements in symptoms such as dyspnoea, anxiety and mobility, as well as depression [51, 52].

In the third study, an intervention bundle including counselling and reporting of depression to the healthcare team was investigated in patients hospitalised with AECOPD. However, the intervention did not significantly affect depression [34].

\section{Discussion}

The reviewed publications uniformly confirm that depression is a common, relevant and problematic comorbidity in patients with COPD [8]. In addition, depression is known to be associated with higher rates of readmission and increased mortality after hospitalisations due to AECOPD [44, 46]. However, these studies are based on heterogeneous patient populations due to differences in applied patient selection criteria. For instance, the prevalence of depression has been applied in some studies as a baseline value for depression, while others use it as an exclusion criterion $[45,47,48,53]$. Presumably, this is the main reason for the differences in the prevalence of depression among the included studies, which ranges from slightly below $10 \%$ to almost $90 \%$. These prevalences are considerably higher than in the general population and similar to those in diseases such as cancer [54] and persons infected with HIV [55]. Furthermore, different measures of depressive symptoms and depression and different cut-off thresholds have been applied. The tool used most commonly was the Hospital Anxiety and Depression Scale 
TABLE 3 Studies that met the inclusion criteria and were reviewed

\begin{tabular}{|c|c|c|c|c|c|c|}
\hline $\begin{array}{l}\text { First author (year) } \\
\text { [ref.] }\end{array}$ & $\begin{array}{c}\text { Study type and characteristics } \\
\text { of study population }\end{array}$ & Patients n & Evaluation of depression & Readmissions & Mortality & Follow-up \\
\hline Abrams (2011) [22] & $\begin{array}{c}\text { Retrospective study of mostly } \\
\text { male }(97 \%) \text { veterans from } \\
2006 \text { to } 2008 \text { hospitalised for } \\
\text { AECOPD }\end{array}$ & 26591 & Prevalent in $11.6 \%(n=3077)$ & $\begin{array}{c}\text { In a } 30 \text {-day period } 10.4 \% \\
\text { (n=319) with prevalent } \\
\text { depression versus } 11.6 \% \\
\text { (n=2723) with no depression }\end{array}$ & $\begin{array}{c}\text { In a } 30 \text {-day period } 5.3 \% \text { ( } n=163 \text { ) } \\
\text { with prevalent depression } \\
\text { versus } 3.8 \%(n=881 \text { ) with no } \\
\text { depression }\end{array}$ & 30 days \\
\hline Regvat (2011) [45] & $\begin{array}{l}\text { Prospective study of patients } \\
\text { hospitalised for AECOPD } \\
\text { Patients with prevalent } \\
\text { psychiatric disorders, } \\
\text { including depression, were } \\
\text { excluded }\end{array}$ & 50 & $\begin{array}{l}\text { Evaluation of depression } \\
\text { through PRIME-MD } \\
\text { questionnaire on day of } \\
\text { discharge; } 42 \% \text { ( }=21 \text { ) } \\
\text { indicated depression }\end{array}$ & $\mathrm{n} / \mathrm{a}$ & $\mathrm{n} / \mathrm{a}$ & $\mathrm{n} / \mathrm{a}$ \\
\hline Pumar (2014) [8] & Review & $\mathrm{n} / \mathrm{a}$ & $\mathrm{n} / \mathrm{a}$ & $\mathrm{n} / \mathrm{a}$ & $\mathrm{n} / \mathrm{a}$ & $\mathrm{n} / \mathrm{a}$ \\
\hline SINGH (2016) [48] & $\begin{array}{l}\text { Retrospective cohorts of } \\
\text { patients hospitalised for } \\
\text { AECOPD in 2001-2011 and } \\
\text { aged }>66 \text { years }\end{array}$ & $\begin{array}{c}80088 \text { patients with } \\
\text { a total of } 135498 \\
\text { hospitalisations }\end{array}$ & $\begin{array}{c}\text { Prevalent in } 14.24 \% \text { of } \\
\text { hospitalisations ( } n=19293 \text { ) }\end{array}$ & $\begin{array}{l}\text { In a } 30 \text {-day period } 24.15 \% \\
\text { ( } \mathrm{n}=4659 \text { ) with prevalent } \\
\text { depression versus } 16.91(\mathrm{n}=19 \\
\text { 645) with no depression }\end{array}$ & $\mathrm{n} / \mathrm{a}$ & 30 days \\
\hline NG $(2014)[40]$ & $\begin{array}{l}\text { Prospective cohort study of } \\
\text { patients hospitalised for } \\
\text { AECOPD } \\
\text { Conference abstract }\end{array}$ & 376 & $\begin{array}{c}\text { HADS score } \geqslant 8 \text { in } 44.4 \% \\
(n=167)\end{array}$ & $\mathrm{n} / \mathrm{a}$ & $\begin{array}{l}\text { In a 1-year period a hazard } \\
\text { ratio of } 1.93(95 \% \mathrm{Cl} 1.04-3.58) \\
\text { for mortality was associated } \\
\text { with baseline depression }\end{array}$ & 1 year \\
\hline Cavaillès (2013) [29] & Review & $\mathrm{n} / \mathrm{a}$ & $\mathrm{n} / \mathrm{a}$ & $\mathrm{n} / \mathrm{a}$ & $\mathrm{n} / \mathrm{a}$ & $\mathrm{n} / \mathrm{a}$ \\
\hline IRWIN (2015) [33] & $\begin{array}{l}\text { Prospective study of patients } \\
\text { hospitalised for AECOPD } \\
\text { Patients with prevalent } \\
\text { psychiatric disorders, including } \\
\text { depression, were excluded }\end{array}$ & 85 & $\begin{array}{l}\text { PROMIS measurement of } \\
\text { depression was positive in } \\
44 \%(\mathrm{n}=35)\end{array}$ & $\mathrm{n} / \mathrm{a}$ & $\mathrm{n} / \mathrm{a}$ & $\mathrm{n} / \mathrm{a}$ \\
\hline SALTE (2015) [46] & Review & $\mathrm{n} / \mathrm{a}$ & $\mathrm{n} / \mathrm{a}$ & $\mathrm{n} / \mathrm{a}$ & $\mathrm{n} / \mathrm{a}$ & $\mathrm{n} / \mathrm{a}$ \\
\hline Aimonino (2007) [23] & $\begin{array}{l}\text { Prospective study of patients } \\
\text { aged } \geqslant 75 \text { years hospitalised } \\
\text { for AECOPD from April } 2004 \text { to } \\
\text { April } 2005\end{array}$ & 16 & $\begin{array}{c}\text { Geriatric depression scale } \\
\text { Mean } \pm \text { SD depression score } \\
\text { of } 12.8 \pm 5.4 \text { at baseline and } \\
12.68 \pm n / a \text { at discharge }\end{array}$ & $\mathrm{n} / \mathrm{a}$ & $\mathrm{n} / \mathrm{a}$ & $\mathrm{n} / \mathrm{a}$ \\
\hline YILDIRIM (2013) [53] & $\begin{array}{l}\text { Prospective study of patients } \\
\text { hospitalised for AECOPD } \\
\text { Patients with prevalent } \\
\text { psychiatric disorders, including } \\
\text { depression, were excluded }\end{array}$ & 135 & $\begin{array}{l}\text { HADS (Turkish translated } \\
\text { version) score } \geqslant 8 \text { in } 85.6 \% \\
(\mathrm{n}=116)\end{array}$ & $\mathrm{n} / \mathrm{a}$ & $\mathrm{n} / \mathrm{a}$ & $\mathrm{n} / \mathrm{a}$ \\
\hline VALENZA (2014) [52] & $\begin{array}{l}\text { Prospective randomised cohort } \\
\text { study of male patients } \\
\text { hospitalised for AECOPD } \\
\text { Intervention with a controlled } \\
\text { breathing programme }\end{array}$ & 46 & $\begin{array}{l}\text { Baseline mean } \pm \text { SD HADS } \\
\text { score of } 9.62 \pm 2.1 \text { in the } \\
\text { intervention group and } \\
8.85 \pm 4 \text { in the control group }\end{array}$ & $\mathrm{n} / \mathrm{a}$ & $\mathrm{n} / \mathrm{a}$ & $\mathrm{n} / \mathrm{a}$ \\
\hline
\end{tabular}




\begin{tabular}{|c|c|c|c|c|c|c|}
\hline $\begin{array}{l}\text { First author (year) } \\
\text { [ref.] }\end{array}$ & $\begin{array}{c}\text { Study type and characteristics } \\
\text { of study population }\end{array}$ & Patients n & Evaluation of depression & Readmissions & Mortality & Follow-up \\
\hline AL AqQAD (2014) [25] & $\begin{array}{c}\text { Prospective study from } \\
\text { January } 2016 \text { to June } 2016 \text { in } \\
\text { Malaysia } \\
\text { Patients hospitalised for } \\
\text { AECOPD and aged }>60 \text { years } \\
\text { Conference abstract }\end{array}$ & 37 & $\begin{array}{l}45.9 \% \text { showed symptoms of } \\
\text { depression (no further } \\
\text { clarification of test } \\
\text { method); } 5.4 \% \text { categorised } \\
\text { as severe and } 40.5 \% \text { as } \\
\text { mild to moderate }\end{array}$ & $\mathrm{n} / \mathrm{a}$ & $\mathrm{n} / \mathrm{a}$ & $\mathrm{n} / \mathrm{a}$ \\
\hline PoOLER (2014) [44] & Review & $\mathrm{n} / \mathrm{a}$ & $\mathrm{n} / \mathrm{a}$ & $\mathrm{n} / \mathrm{a}$ & $\mathrm{n} / \mathrm{a}$ & $\mathrm{n} / \mathrm{a}$ \\
\hline LAURIN (2012) [39] & Review & $\mathrm{n} / \mathrm{a}$ & $\mathrm{n} / \mathrm{a}$ & $\mathrm{n} / \mathrm{a}$ & $\mathrm{n} / \mathrm{a}$ & $\mathrm{n} / \mathrm{a}$ \\
\hline $\begin{array}{l}\text { PapaloanNou } \\
\text { (2013) [43] }\end{array}$ & $\begin{array}{l}\text { Prospective study of patients } \\
\text { hospitalised for AECOPD } \\
\text { between March } 2009 \text { and June } \\
2010 \text { without prevalent } \\
\text { depression }\end{array}$ & 230 & $\begin{array}{l}\text { Beck depression inventory } \\
\text { (Greek translation) score } \\
\geqslant 19 \text { in } 39.57 \% \text { ( } n=91 \text { ) on the } \\
\text { first day of hospitalisation }\end{array}$ & $\begin{array}{c}84.6 \%(n=77) \text { with } 1.96 \pm 1.41 \\
\text { readmissions for depressive } \\
\text { patients versus } 28.1 \%(n=39) \\
\text { with } 0.41 \pm 0.86 \text { readmissions for } \\
\text { nondepressive patients within } \\
\quad 1 \text { year }\end{array}$ & $\begin{array}{c}25.3 \%(n=23) \text { for depressive } \\
\text { patients versus } 3.6 \%(n=5) \text { for } \\
\text { nondepressive patients within } \\
1 \text { year }\end{array}$ & 1 year \\
\hline LAURIN (2011) [38] & Review & $\mathrm{n} / \mathrm{a}$ & $\mathrm{n} / \mathrm{a}$ & $\mathrm{n} / \mathrm{a}$ & $\mathrm{n} / \mathrm{a}$ & $\mathrm{n} / \mathrm{a}$ \\
\hline $\begin{array}{l}\text { OZYEMISCI-TASKIRAN } \\
\text { (2015) [41] }\end{array}$ & $\begin{array}{l}\text { Retrospective study of patients } \\
\text { hospitalised for AECOPD } \\
\text { Two hospitalised control } \\
\text { groups: one with stable COPD } \\
\text { and one without COPD }\end{array}$ & $\begin{array}{l}133 \text { (AECOPD); } 34 \\
\text { (stable COPD); } 34 \\
\text { (without COPD) }\end{array}$ & $\begin{array}{c}\text { HADS (Turkish translation) } \\
\text { score } \geqslant 8 \text { in } 39.1 \%(n=52) ; \\
\text { mean score } 5(Q 1=2 ; Q 3=11) \\
\text { for } A E C O P D \\
\text { HADS score } \geqslant 8 \text { in } 14.7 \% \\
(n=5) ; \text { mean score } 4 \\
(Q 1=0.25 ; Q 3=6) \text { for stable } \\
\text { COPD } \\
\text { HADS score } \geqslant 8 \text { in } 29.4 \% \\
(n=10) ; \text { mean score } 4.5 \\
(Q 1=1 ; Q 3=8.25) \text { for } \\
\text { non-COPD }\end{array}$ & $\mathrm{n} / \mathrm{a}$ & $\mathrm{n} / \mathrm{a}$ & $\mathrm{n} / \mathrm{a}$ \\
\hline Almagro (2002) [27] & $\begin{array}{c}\text { Prospective study of patients } \\
\text { (mostly male, } 96 \% \text { ) } \\
\text { hospitalised for AECOPD } \\
\text { between October } 1996 \text { and } \\
\text { May } 1997\end{array}$ & 135 & $\begin{array}{l}\text { YDS was applied, but no } \\
\text { direct data provided }\end{array}$ & $\mathrm{n} / \mathrm{a}$ & $\begin{array}{l}\text { Patients with YDS score } \geqslant 11 \\
\text { had a } 3.11 \text {-fold higher } \\
\text { mortality than patients with a } \\
\text { YDS score } \leqslant 5 \text { within } 2 \text { years }\end{array}$ & 2 years \\
\hline Panagioti (2014) [42] & Review & $\mathrm{n} / \mathrm{a}$ & $\mathrm{n} / \mathrm{a}$ & $\mathrm{n} / \mathrm{a}$ & $\mathrm{n} / \mathrm{a}$ & $\mathrm{n} / \mathrm{a}$ \\
\hline SMall (1992) [49] & $\begin{array}{l}\text { Prospective study of patients } \\
\text { hospitalised for AECOPD }\end{array}$ & 26 & $\begin{array}{l}\text { Profile of Mood States was } \\
\text { applied } \\
\text { Mean } \pm \text { SD score for } \\
\text { depression of } 13.35 \pm 12.38 \\
\text { and median score } 11.5 \\
\text { No cut-off value for } \\
\text { depression was provided by } \\
\text { the test }\end{array}$ & $\mathrm{n} / \mathrm{a}$ & $\mathrm{n} / \mathrm{a}$ & $\mathrm{n} / \mathrm{a}$ \\
\hline
\end{tabular}




\begin{tabular}{|c|c|c|c|c|c|c|}
\hline $\begin{array}{l}\text { First author (year) } \\
\text { [ref.] }\end{array}$ & $\begin{array}{c}\text { Study type and characteristics } \\
\text { of study population }\end{array}$ & Patients $\mathrm{n}$ & Evaluation of depression & Readmissions & Mortality & Follow-up \\
\hline KoENIG (2006) [36] & $\begin{array}{l}\text { Prospective cohort study of } \\
\text { patients aged }>50 \text { years } \\
\text { hospitalised for AECOPD } \\
\text { between November } 1999 \text { and } \\
\text { December } 2003\end{array}$ & $\begin{array}{l}\text { No data provided on } \\
\text { overall rates of } \\
\text { depression of } \\
\text { screened patients }\end{array}$ & $\begin{array}{l}\text { Patients were identified as } \\
\text { depressive using the } \\
\text { Structured Clinical } \\
\text { Interview for Diagnostic and } \\
\text { Statistical Manual of Mental } \\
\text { Disorders (4th edition) } \\
410 \text { patients were classified } \\
\text { with minor deperession and } \\
301 \text { with major depression } \\
\text { using the Hamilton } \\
\text { Depression Rating Scale }\end{array}$ & $\mathrm{n} / \mathrm{a}$ & $\mathrm{n} / \mathrm{a}$ & $\begin{array}{l}\text { At an average follow-up of } \\
11.4 \text { weeks minor } \\
\text { depressions showed } \\
\text { remission of } 66.6 \% \text { ( } n=273 \text { ) } \\
\text { and at an average follow-up } \\
\text { of } 21.3 \text { weeks for major } \\
\text { depressions } 49.2 \% \text { (n=148) } \\
\text { showed remission }\end{array}$ \\
\hline Jennings (2015) [34] & $\begin{array}{l}\text { Randomised trial of patients } \\
\text { admitted with AECOPD } \\
\text { between February } 2010 \text { and } \\
\text { April } 2013 \text { and with smoking } \\
\text { history } \geqslant 20 \text { pack-years }\end{array}$ & $\begin{array}{c}172 \text { in total; } \\
\text { (intervention group } \\
\mathrm{n}=93 \text {; control group } \\
\mathrm{n}=79 \text { ) }\end{array}$ & $\begin{array}{l}\text { HADS was applied in the } \\
\text { intervention group, but no } \\
\text { baseline values are } \\
\text { provided }\end{array}$ & $\begin{array}{c}\text { No significant association } \\
\text { between depression score per } \\
\text { 1-unit increase and } \\
\text { Readmission for } 30 \text {-day } \\
\text { follow-up (HR 1.11, 95\% Cl } \\
0.96-1.27 ; p=0.157 \text { ) and 90-day } \\
\text { follow-up (HR 1.057, 95\% Cl } \\
0.95-1.17 ; p=0.300 \text { ) }\end{array}$ & $\mathrm{n} / \mathrm{a}$ & 30 days and 90 days \\
\hline SILVER (2010) [47] & $\begin{array}{l}\text { Cross-sectional study of } \\
\text { patients hospitalised for } \\
\text { AECOPD between January } \\
2007 \text { and December } 2007 \\
\text { Conference abstract }\end{array}$ & 69841 & $\begin{array}{c}\text { Prevalent diagnosis of } \\
\text { anxiety/depression present } \\
\text { in } 27.3 \% \\
\text { No seperated data provided }\end{array}$ & $\mathrm{n} / \mathrm{a}$ & $\begin{array}{c}\text { Odds ratio for in-hospital } \\
\text { mortality } 0.93(95 \% \mathrm{Cl} 0.81- \\
1.06)\end{array}$ & $\mathrm{n} / \mathrm{a}$ \\
\hline $\begin{array}{l}\text { TORRES-SÁNCHEZ (2016) } \\
\text { [51] }\end{array}$ & $\begin{array}{l}\text { Randomised, single-blind } \\
\text { clinical trial of obese patients } \\
\text { hospitalised for AECOPD }\end{array}$ & $\begin{array}{l}49 \text { (intervention } \\
\text { group } n=24 \text {; control } \\
\text { group } n=25 \text { ) }\end{array}$ & $\begin{array}{c}\text { HADS mean } \pm \text { SD score at } \\
\text { baseline: intervention group } \\
6.0 \pm 2.86 \text {; control group } 4.90 \\
\pm 2.84 \\
p=0.218\end{array}$ & $\mathrm{n} / \mathrm{a}$ & $\mathrm{n} / \mathrm{a}$ & $\begin{array}{c}\text { Follow-up evaluation at } \\
\text { discharge }\end{array}$ \\
\hline Kıм (2010) [35] & $\begin{array}{l}\text { Retrospective study of } 77 \\
\text { patients hospitalised for } \\
\text { AECOPD between January } \\
2005 \text { and May } 2008\end{array}$ & 77 & $\begin{array}{c}\text { Patients with prevalent } \\
\text { diagnosis of anxiety/ } \\
\text { depression and patients } \\
\text { taking psychotropic } \\
\text { medication were considered } \\
\text { to have anxiety/depression } \\
\text { No seperated data of } \\
\text { anxiety/depression were } \\
\text { provided } \\
11.9 \%(n=9) \text { of patients had } \\
\text { anxiety/depression }\end{array}$ & $\begin{array}{l}\text { Frequent exacerbators ( } n=35) \\
\text { (>1 hospitalisation within } \\
1 \text { year) showed } 20 \%(n=7) \\
\text { anxiety/depression versus } 4.8 \% \\
(n=2) \text { of single exacerbators } \\
\text { ( } n=42)\end{array}$ & $\mathrm{n} / \mathrm{a}$ & $\mathrm{n} / \mathrm{a}$ \\
\hline
\end{tabular}


TABLE 3 Continued

First author (year) Study type and characteristics
of study population

of study population

Patients $n$

Evaluation of depression

Readmissions

Mortality

Follow-up

Almagro (2006) [26] Prospective study of patients hospitalised for AECOPD between October 1996 and May 1997

129

YDS was applied, but no general baseline data are provided

YDS mean \pm SD score of $5 \pm 3.4$ for patients who were readmitted within 1 year versus $3.7 \pm 3.1$ for

Score $\geqslant 5$ is considered as patients without readmission cut-off for depression within 1 year

$58.1 \%$ were readmitted within 1 year

Gudmundsson (2005) Prospective study of patients [31] hospitalised for AECOPD during 2000-2001

HADS mean \pm SD score 5.5 $\pm 3.6$

$60.59 \%$ ( $n=246$ ) readmitted within 1 year versus $39.41 \%$ HADS score $\geqslant 8$ in $28.7 \% \quad(n=160)$ without readmission in 1 year

No significant difference between groups in mean HADS score $(5.4 \pm 3.4$ versus $5.6 \pm 3.8$; $p=0.63$ ) and depression level (26.5\% versus $30.2 \%$; $p=0.44$ )

StRUIK (2013) [50]

Cross-sectional study of patients hospitalised for AECOPD between 2008 and October 2011 with GOLD III or IV disease and after $48 \mathrm{~h}$ of receiving invasive or noninvasive ventilation

Aimonino Ricauda (2008) [24]

Prospective study of patients aged $\geqslant 75$ years hospitalised for AECOPD between April

$$
2004 \text { and April } 2005
$$

The authors published similar article including partly the same population in 2007 [27]

Abrams (2010) [21] Retrospective cohort study of veterans hospitalised for AECOPD between October 2016 and September 2007 Conference abstract
$17.2 \pm 6.8$ at baseline and a mean \pm SD change of +0.7 $\pm 3.2 \%$ at 6 -month follow-up

Pre-existing depression was assessed from data collected 1 year prior to admission

$9.5 \%(n=2.216)$ had pre-existing depression

Unadjusted 365-day mortality was similar in patients with depression $19.8 \%$ versus $9.1 \%$ $\mathrm{n} / \mathrm{a}$

1 year

$n / a$

1 year Adjusted odds ratio of 30-day mortality with depression without 1.52 $195 \% \mathrm{Cl} 1.24-1.86)$; adjusted odds ratio of 365-day mortality with depression relative to those without $1.2195 \% \mathrm{Cl}$

$$
\text { 1.04-1.39] }
$$


TABLE 3 Continued

First author (year) Study type and characteristics [ref.]

type and characteristics

Patients n

Evaluation of depression

Readmissions

Mortality

BURR (2010) [28]

Retrospective study of patients hospitalised for AECOPD in 2008

Frequent exacerbators $n=85$;

Depression prevatent in $42 \%$ of frequent

$\mathrm{n} / \mathrm{a}$

$\mathrm{n} / \mathrm{a}$

$\mathrm{n} / \mathrm{a}$

Two groups where defined: nonfrequent exacerbators

frequent exacerbators $(>1$ AECOPD event in 2008) and single AECOPD event in 2008 Conference abstract

Aaron (2013) [20] Retrospective study of patients hospitalised for AECOPD in

$$
2010
$$

Conference abstract

LAC̣IN (2011) [37]

Study of patients hospitalised for AECOPD between January 2010 and February 2011

Conference abstract

HaSAN (2011) [32] Study of patients hospitalised for AECOPD

Patients with pneumonia, heart failure, on long-term oral corticosteroids, any significant comorbid condition or active malignancy were excluded

Conference abstract

Franzen (2014) [30] Study of patients hospitalised between January 2012 and December 2012 in three public hospitals in Zurich canton for AECOPD

Conference abstract

114

S was applied within

2 days of hospitalisation HADS scores $\geqslant 11$ in $28 \%$ $(n=34)$

HADS score $\geqslant 8$ in $53 \%$ $(n=60)$, mean \pm SD HADS score $7.0 \pm 5.7$

The study does not distinguish between depression and anxiety $29 \%$ of patients with prevalent depression/anxiety where readmitted within 1 year versus $16 \%$ of patients without depression/anxiety

$\mathrm{n} / \mathrm{a}$

AECOPD: acute exacerbation of chronic obstructive pulmonary disease; PRIME-MD: Primary Care Evaluation of Mental Disorders; HADS: Hospital Anxiety and Depression Scale; PROMIS: Patient-reported Outcomes Measurement Information System; YDS: Yesavage Depression Scale; GOLD: Global Initiative for Chronic Obstructive Lung Disease. 
(HADS), a questionnaire containing 14 questions, of which seven are targeted at symptoms of anxiety and seven at symptoms of depression. Each question is scored from 0 to 3, which gives a minimum/maximum scale of 0-21 individually for depression and anxiety. Somatic symptoms are not assessed to detect depression more reliably in patients with physical health problems [56]. Yet in the studies using the HADS, the reported prevalence of depression varied extensively, ranging from $25 \%$ to $85 \%$ [20-28, 30-37, $40,41,43,45,47-53]$. It is possible that there are language-related differences in the psychometric properties of the HADS in different countries, despite a good internal consistency (i.e. Cronbach's $\alpha$ ). Furthermore, versions of the HADS in some languages favour three- or four-factor models rather than the two-factor model applied to the HADS [57].

The identified studies indicate a higher readmission rate in depressive patients hospitalised for AECOPD and higher mortality after discharge. Thus, we tentatively conclude that in AECOPD depression strongly relates to poorer outcomes. Hence, further studies with larger patient samples are needed to more precisely investigate the association between AECOPD and depression [2]. Results from the present review suggest that there is potential and substantial benefit to be gained by early screening for and treatment of depression in patients hospitalised for AECOPD. In addition, it would be of interest for further studies to analyse whether the rate of depression in these patients is associated with other frequent somatic comorbidities in COPD (i.e. right heart failure, diabetes, kidney insufficiency and amyotrophy), as this has not been addressed in the identified literature.

Furthermore, we aimed to summarise recommendations given in the studies investigated in this article for the screening and management of depressive mood disorders in patients hospitalised due to AECOPD. Disappointingly, none of these publications provided any specific suggestions or recommendations. However, the wide range of the reported prevalence of depression among these patients suggests that further development and validation of screening methods for depression in patients hospitalised for AECOPD is needed. This would help to ensure the reliability of measures like the HADS or the two- and nine-question patient health questionnaires (PHQ-2 and PHQ-9) specifically for AECOPD. For the purpose of enhancing cross-national standards of screening, this might also include consideration of potential differences in response style of respondents (and specifically patients) across different countries (and languages) in self-report instruments [58].

We found little information on the management of depression in AECOPD patients in the publications included in this study. None of the publications address the use of psychotherapy or the initiation of antidepressive medication in patients hospitalised for AECOPD. Two interventional studies indicated an improvement of depressive symptoms in patients treated with an adjusted physical therapy regime during the acute phase of AECOPD [51, 52], although it should be noted that these findings were based on very small patient samples in both studies.

The impact of reporting the presence of depressive symptoms to primary care and acute care medical teams was examined in one study, but reporting led to no significant improvement in readmission rates [34]. Importantly, it was not assessed whether this information actually resulted in adjustment of the therapy.

KoENIG [36] found that depressive patients hospitalised for AECOPD and treated with antidepressants had more severe and prolonged depressions. A possible explanation for this finding might be that medication was only given to patients with more severe depression. It is notable that only $46.2 \%$ of patients identified as depressive received antidepressant medication, and only $14.6 \%$ received any form of psychotherapy. Intervention studies on early onset of psychiatric treatment (antidepressive medication and/or psychotherapy) are urgently needed, especially regarding our findings on the outcome of hospitalised AECOPD patients with depression.

Although there is a lack of data on the effects of therapy adjustment, we recommend basic screening for depression (e.g. HADS or PHQ-9) in all patients hospitalised for AECOPD. As guidelines for HIV patients recommend screening for depression of these at-risk patients [55] and the US Preventive Services Task Force recommends screening of all patients [59], it is indispensable to screen for depression in this high-risk patient population.

In summary, the present review demonstrates that depression in patients hospitalised for AECOPD is common, irrespective of the method used to assess depression and the selection criteria applied for recruiting patients for the studies. The present review shows also that extremely little research has been conducted on how to best manage these patients. The outlook of the studies included in this review is consistent with the idea that more systematic application of validated interventions for AECOPD patients with depression should be developed. In fact, prospective and randomised studies to identify optimal screening for depression and to assess potential improvements of outcomes with different treatment 
modalities of depression are urgently required in this group of patients. Thus, prospective randomised interventional clinical studies on the effect of therapy adjustments such as early psychotherapeutic interventions, antidepressant medication and intensified physical therapy in depressive patients hospitalised with a primary diagnosis of AECOPD are needed.

\section{Conclusion}

The co-occurrence of AECOPD and depression seems to result in increased readmission rates and long-term mortality. However, data on screening and management of depressive patients with AECOPD are scarce and heterogeneous. Further studies are urgently needed to adapt screening tools for depression in AECOPD and to investigate potential therapeutic interventions and their effect on the outcome.

\section{References}

1 de Godoy DV, de Godoy RF. A randomized controlled trial of the effect of psychotherapy on anxiety and depression in chronic obstructive pulmonary disease. Arch Phys Med Rehabil 2003; 84: 1154-1157.

2 Hynninen $\mathrm{KM}$, Breitve $\mathrm{MH}$, Wiborg $\mathrm{AB}$, et al. Psychological characteristics of patients with chronic obstructive pulmonary disease: a review. J Psychosom Res 2005; 59: 429-443.

3 Anderson KL. The effect of chronic obstructive pulmonary disease on quality of life. Res Nurs Health 1995; 18: $547-556$

4 Kaptein AA, Brand PL, Dekker FW, et al. Quality-of-life in a long-term multicentre trial in chronic nonspecific lung disease: assessment at baseline. The Dutch CNSLD Study Group. Eur Respir J 1993; 6: 1479-1484.

5 Kim HF, Kunik ME, Molinari VA, et al. Functional impairment in COPD patients: the impact of anxiety and depression. Psychosomatics 2000; 41: 465-471.

6 Atlantis E, Fahey P, Cochrane B, et al. Bidirectional associations between clinically relevant depression or anxiety and COPD: a systematic review and meta-analysis. Chest 2013; 144: 766-777.

7 Ng TP, Niti M, Tan WC, et al. Depressive symptoms and chronic obstructive pulmonary disease: effect on mortality, hospital readmission, symptom burden, functional status, and quality of life. Arch Intern Med 2007; 167: 60-67.

8 Pumar MI, Gray CR, Walsh JR, et al. Anxiety and depression - important psychological comorbidities of COPD. J Thorac Dis 2014; 6: 1615-1631.

9 Decramer M, Rennard S, Troosters T, et al. COPD as a lung disease with systemic consequences - clinical impact, mechanisms, and potential for early intervention. COPD 2008; 5: 235-256.

10 Wagena EJ, Arrindell WA, Wouters EF, et al. Are patients with COPD psychologically distressed? Eur Respir J 2005; 26: 242-248.

11 Horowitz MA, Zunszain PA, Anacker C, et al. Glucocorticoids and inflammation: a double-headed sword in depression? How do neuroendocrine and inflammatory pathways interact during stress to contribute to the pathogenesis of depression? Mod Trends Pharmacopsychiatry 2013; 28: 127-143.

12 Brown ES, Vera E, Frol AB, et al. Effects of chronic prednisone therapy on mood and memory. J Affect Disord 2007; 99: 279-283.

13 Brown ES, Suppes T, Khan DA, et al. Mood changes during prednisone bursts in outpatients with asthma. J Clin Psychopharmacol 2002; 22: 55-61.

14 Naber D, Sand P, Heigl B. Psychopathological and neuropsychological effects of 8-days' corticosteroid treatment. A prospective study. Psychoneuroendocrinology 1996; 21: 25-31.

15 Russi EW, Karrer W, Brutsche M, et al. Diagnosis and management of chronic obstructive pulmonary disease: the Swiss guidelines. Official guidelines of the Swiss Respiratory Society. Respiration 2013; 85: 160-174.

16 Global Initiative for Chronic Obstructive Lung Disease. GOLD 2017 Global Strategy for the Diagnosis, Management and Prevention of Chronic Obstructive Pulmonary Disease. http://goldcopd.org/ gold-2017-global-strategy-diagnosis-management-prevention-copd/ Date last accessed: December 14, 2016.

17 National Institute for Health and Care Excellence. Chronic Obstructive Pulmonary Disease in Over 16s: Diagnosis and Management. www.nice.org.uk/guidance/cg101 Date last accessed: December 14, 2016. Date last updated: June 2010.

18 Harris JD, Quatman CE, Manring MM, et al. How to write a systematic review. Am J Sports Med 2014; 42: 2761-2768.

19 Liberati A, Altman DG, Tetzlaff J, et al. The PRISMA statement for reporting systematic reviews and meta-analyses of studies that evaluate health care interventions: explanation and elaboration. J Clin Epidemiol 2009; 62: e1-e34.

20 Aaron CP, Yip NH, Brinson MD, et al. Chronic obstructive pulmonary disease hospitalizations in 2010: factors associated with readmission. Am J Respir Crit Care Med 2013; 187: A4384.

21 Abrams T, Rosenthal G, Sarrazin M. Assessing the impact of anxiety and depression on chronic obstructive lung disease mortality. J Gen Intern Med 2010; 25: S225.

22 Abrams TE, Vaughan-Sarrazin M, Vander Weg MW. Acute exacerbations of chronic obstructive pulmonary disease and the effect of existing psychiatric comorbidity on subsequent mortality. Psychosomatics 2011; 52: 441-449.

23 Aimonino N, Tibaldi V, Barale S, et al. Depressive symptoms and quality of life in elderly patients with exacerbation of chronic obstructive pulmonary disease or cardiac heart failure: preliminary data of a randomized controlled trial. Arch Gerontol Geriatr 2007; 44: Suppl. 1, 7-12.

24 Aimonino Ricauda N, Tibaldi V, Leff B, et al. Substitutive "hospital at home" versus inpatient care for elderly patients with exacerbations of chronic obstructive pulmonary disease: a prospective randomized, controlled trial. J Am Geriatr Soc 2008; 56: 493-500.

25 Al Aqqad S, Ali I, Kassim R, et al. Evaluation of the characteristics, anxiety, and depression among older patients hospitalized for acute exacerbations of chronic obstructive pulmonary disease. Chest 2014; 145: 393A. 
26 Almagro P, Barreiro B, Ochoa de Echaguen A, et al. Risk factors for hospital readmission in patients with chronic obstructive pulmonary disease. Respiration 2006; 73: 311-317.

27 Almagro P, Calbo E, Ochoa de Echagüen, et al. Mortality after hospitalization for COPD. Chest 2002; 121: 1441-1448.

28 Burr L, Tay G, Tang T, et al. Characteristics of the frequent COPD exacerbators at the Gold Coast hospital. Respirology 2010; 15: A60.

29 Cavaillès A, Brinchault-Rabin G, Dixmier A, et al. Comorbidities of COPD. Eur Respir Rev 2013; 22: $454-475$.

30 Franzen D, Graf F, Wieser S, et al. Hospital care patterns in the management of acute exacerbated chronic obstructive pulmonary disease - a retrospective analysis from Zurich, Switzerland. Eur Respir J 2014; 44: Suppl. $58,795$.

31 Gudmundsson G, Gislason T, Janson C, et al. Risk factors for rehospitalisation in COPD: role of health status, anxiety and depression. Eur Respir J 2005; 26: 414-419.

32 Hasan MI, Haque R, Smyth C. Depression in chronic obstructive pulmonary disease - ignoring the obvious. Am J Respir Crit Care Med 2011; 183: A2987.

33 Irwin DE, Atwood CA Jr, Hays RD, et al. Correlation of PROMIS scales and clinical measures among chronic obstructive pulmonary disease patients with and without exacerbations. Qual Life Res 2015; 24: 999-1009.

34 Jennings JH, Thavarajah K, Mendez MP, et al. Predischarge bundle for patients with acute exacerbations of chronic obstructive pulmonary disease to reduce readmissions and ED visits: a randomized, controlled trial. Chest 2015; 147: 1227-1234.

35 Kim MH, Lee K, Kim KU, et al. Risk factors associated with frequent hospital readmissions for exacerbation of COPD. Tuberc Respir Dis 2010; 69: 243-249.

36 Koenig HG. Predictors of depression outcomes in medical inpatients with chronic pulmonary disease. Am $J$ Geriatr Psychiatry 2006; 14: 939-948.

37 Laçin A, Taskiran OO, Köktürk N, et al. Depression and related factors in pulmonary rehabilitation patients with chronic obstructive pulmonary disease during exacerbation. Turkiye Fiziksel Tip ve Rehabilitasyon Dergisi 2011; 57: 276.

38 Laurin C, Moullec G, Bacon SL, et al. The impact of psychological distress on exacerbation rates in COPD. Ther Adv Respir Dis 2011; 5: 3-18.

39 Laurin C, Moullec G, Bacon SL, et al. Impact of anxiety and depression on chronic obstructive pulmonary disease exacerbation risk. Am J Respir Crit Care Med 2012; 185: 918-923.

$40 \mathrm{Ng}$ TP, Niti M, Tan WC, et al. Clinical impact of comorbid depressive symptoms among patients with chronic obstructive pulmonary disease. Ann Acad Med Singap 2014; 43: S58.

41 Ozyemisci-Taskiran O, Bozkurt SO, Kokturk N, et al. Is there any association between cognitive status and functional capacity during exacerbation of chronic obstructive pulmonary disease? Chron Respir Dis 2015; 12: 247-255.

42 Panagioti M, Scott C, Blakemore A, et al. Overview of the prevalence, impact, and management of depression and anxiety in chronic obstructive pulmonary disease. Int J Chron Obstruct Pulmon Dis 2014; 9: 1289-1306.

43 Papaioannou AI, Bartziokas K, Tsikrika S, et al. The impact of depressive symptoms on recovery and outcome of hospitalised COPD exacerbations. Eur Respir J 2013; 41: 815-823.

44 Pooler A, Beech R. Examining the relationship between anxiety and depression and exacerbations of COPD which result in hospital admission: a systematic review. Int J Chron Obstruct Pulmon Dis 2014; 9: 315-330.

45 Regvat J, Žmitek A, Vegnuti M, et al. Anxiety and depression during hospital treatment of exacerbation of chronic obstructive pulmonary disease. J Int Med Res 2011; 39: 1028-1038.

46 Salte K, Titlestad I, Halling A. Depression is associated with poor prognosis in patients with chronic obstructive pulmonary disease - a systematic review. Dan Med J 2015; 62: A5137.

47 Silver H, Blanchette CM, Roberts M, et al. Prevalence of comorbidities in patients hospitalized for COPD exacerbations and impact on impatient mortality and hospital expenditures. Am J Respir Crit Care Med 2010; 181: A5943.

48 Singh G, Zhang W, Kuo YF, et al. Association of psychological disorders with 30-day readmission rates in patients with COPD. Chest 2016; 149: 905-915.

49 Small SP, Graydon JE. Perceived uncertainty, physical symptoms, and negative mood in hospitalized patients with chronic obstructive pulmonary disease. Heart Lung 1992; 21: 568-574.

50 Struik FM, Kerstjens HA, Bladder G, et al. The Severe Respiratory Insufficiency Questionnaire scored best in the assessment of health-related quality of life in chronic obstructive pulmonary disease. J Clin Epidemiol 2013; 66: 1166-1174.

51 Torres-Sánchez I, Valenza MC, Sáez-Roca G, et al. Results of a multimodal program during hospitalization in obese COPD exacerbated patients. COPD 2016; 13: 19-25.

52 Valenza MC, Valenza-Peña G, Torres-Sánchez I, et al. Effectiveness of controlled breathing techniques on anxiety and depression in hospitalized patients with COPD: a randomized clinical trial. Respir Care 2014; 59: $209-215$.

53 Yıldırım A, Aşilar RH, Bakar N, et al. Effect of anxiety and depression on self-care agency and quality of life in hospitalized patients with chronic obstructive pulmonary disease: a questionnaire survey. Int J Nurs Pract 2013; 19: 14-22.

54 Smith HR. Depression in cancer patients: pathogenesis, implications and treatment (review). Oncol Lett 2015; 9: 1509-1514.

55 European AIDS Clinical Society. Guidelines Version 8.1. www.eacsociety.org/files/guidelines_8.1-english.pdf Date last accessed: November 3, 2016. Date last updated: October 2016.

56 Zigmond AS, Snaith RP. The hospital anxiety and depression scale. Acta Psychiatr Scand 1983; 67: 361-370.

57 Bjelland I, Dahl AA, Haug TT, et al. The validity of the hospital anxiety and depression scale. An updated literature review. J Psychosom Res 2002; 52: 69-77.

58 Harzing A-W. Response styles in cross-national survey research: a 26-country study. Int J Cross Cult Manag 2006 6: 243-266.

59 Siu AL. Screening for depression in children and adolescents: US Preventive Services Task Force recommendation statement. Pediatrics 2016; 137: e20154467. 